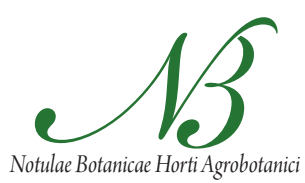

Cluj-Napoca

\title{
Auxin Control in the Formation of Adventitious Roots
}

\author{
Tiberia I. POP1,2, Doru PAMFIL', Catherine BELLINI²,3 \\ ${ }^{1}$ University of Agricultural Sciences and Veterinary Medicine, 3-5 Mănăstur, Cluj-Napoca, Romania; tiberiapop@yahoo.com \\ ${ }^{2}$ Umeå Plant Science Centre, Department of Plant Physiology, Umeå University, 90187 Umeå, Sweden; Catherine.Bellini@plantphys.umu.se \\ ${ }^{3}$ Institut Jean-Pierre Bourgin, UMR 1318 INRA-AgroParisTech, INRA Centre de Versailles-Grignon, F-78026 Versailles Cedex, France
}

\begin{abstract}
Adventitious rooting is a complex process and a key step in the vegetative propagation of economically important woody, horticultural and agricultural species, playing an important role in the successful production of elite clones. The formation of adventitious roots is a quantitative genetic trait regulated by both environmental and endogenous factors. Among phytohormones, auxin plays an essential role in regulating roots development and it has been shown to be intimately involved in the process of adventitious rooting. Great progress has been made in elucidating the auxin-induced genes and auxin signaling pathway, especially in auxin response Aux/IAA and Auxin Response Factor gene families. Although some important aspects of adventitious and lateral rooting signaling have been revealed, the intricate signaling network remains poorly understood. This review summarizes some of the current knowledge on the physiological aspects of adventitious root formation and highlights the recent progress made in the identification of putative molecular players involved in the control of adventitious rooting. Despite much has been discovered regarding the effects and regulation of auxins on plant growth since the Darwin experiments, there is much that remains unknown.
\end{abstract}

Keywords: Aux/IAA, Auxin Response Factor, shoot-born roots, vegetative propagation

\section{Introduction to adventitious roots}

Vegetative propagation is extensively used in agriculture, horticulture and forestry for multiplying elite plants selected from natural populations or obtained in breeding programs (Hartmann et al., 1990). The formation of adventitious roots is an essential step in vegetative propagation and therefore if cuttings do not form roots, losses occur (de Klerk et al., 1999). Researchers developed new rooting treatments, examining the effects of plant growth regulators (Haissig and Davis, 1994) by a short exposure to a solution with a high auxin concentration or by dipping in rooting powder (auxin with talc). Noticeable progress has been made recently in the research on rooting, which is not a single process but a progressive process consisting of different steps, each with its own requirements (Kevers et al., 1997).

Plant development is modulated by genetic and environmental factors, which have effects on auxin biosynthesis, metabolism, transport, and signaling pathway (Han et al., 2009). Recent advances in studying mutations of Arabidopsis and rice increased the understanding of the role of auxin in the regulation of rooting mechanisms and molecular studies are essential to reveal the basic mechanisms operating in adventitious root formation (de Klerk et al., 1999). Many dicots like Arabidopsis thaliana have a primary root that branches to generate several orders of lateral roots, while the root systems of crops like rice and maize are predominantly composed of adventitious roots (Hochholdinger et al., 2004; Osmont et al., 2007).

Definition. Adventitious roots can arise naturally from stem tissue under stressful environmental conditions; they may also be induced by mechanical damage or following tissue culture regeneration of shoots (Li et al., 2009). They are postembryonic roots which arise from the stem and leaves and from nonpericycle tissues in old roots (Geiss et al., 2009). There are at least two pathways by which adventitious roots form: by direct organogenesis from established cell types such as the cambium or from callus tissue following mechanical damage (e.g. cuttings).

Induction phases. Rooting phases, which can be distinguished in various ways, have different hormone requirements (de Klerk et al., 1999). De Klerk et al. (1997) showed that apple microcuttings are not very sensitive to auxin and cytokinin during the first $24 \mathrm{~h}$. Dedifferentiation occurs during this lag period and cells can respond to auxin. The root primordia originates from the cells between the vascular bundles which accumulate starch during the initial $24 \mathrm{~h}$. Between 72-96 h, activated cells become committed to the formation of root primordia by the rhizogenic action of auxin in the induction phase, when auxin pulses induce the highest number of roots. On the histological level the starch grains present at $24 \mathrm{~h}$ are degraded during the next $24 \mathrm{~h}$, the first cell divisions occurring on the first $48 \mathrm{~h}$ and by $96 \mathrm{~h}$ meristemoids are present. Auxin is not required after $96 \mathrm{~h}$ and the concentrations favorable 
308

for the meristemoids formation become inhibitory during this phase. The meristemoids develop into root primordia and further into roots during the differentiation phase (de Klerk et al., 1999).

\section{The plant hormone auxin}

Auxins, cytokinins, gibberellins, abscisic acid and ethylene are the five classical groups of plant hormones (Kende and Zeevaart, 1997). Ideas about hormone function have evolved from numerous experiments in which the application of the hormones have shown to affect cell division in the vascular cambium, cell expansion and control of differentiation into different types of cambial derivates (Mellerowicz et al., 2001).

The formation of adventitious roots is a process induced and regulated by environmental and endogenous factors, such as temperature, light, hormones (especially auxin), sugars, mineral salts and other molecules. Phytohormones have direct (involved in cell division or cell growth) or indirect (interacting with other hormones or molecules) effects on plants. Over the last years, a multitude of models have been proposed to show how plant hormones interact to control plant development (Jaillais and Chory, 2010; Nemhauser et al., 2006; Santner and Estelle, 2009).

Auxins are a group of tryptophan-derived signals, which are involved in most aspects of plant development (Woodward and Bartel, 2005). Auxin plays a major role in controlling growth and development of plants, early stages of embryogenesis, organization of apical meristem (phyllotaxy) and branching of the plant aerial parts (apical dominance), formation of main root, lateral and adventitious root initiation (Went and Thimann, 1937). Auxin is also involved in gravitropism and phototropism (Kepinski and Leyser, 2005). These multiple effects across the plant result from its control of cell division, cell elongation and certain stages of differentiation (Davies, 2004). Auxin is synthesized mainly in young leaves and is actively transported to other tissues to coordinate growth and facilitate responses to environmental variations.

Discovery and history. The first observations suggesting the presence of a chemical substance modifying plant growth in response to unilateral illumination date from 1880, when Darwin published "The power of movement in plants". Tips of plants exposed to light curved toward the light, which led Darwin to believe that a chemical messenger transports a signal from the coleoptile to the rest of the plant (Darwin, 1880). In 1913, Peter Boysen-Jensen removed the coleoptiles and plants growth stopped and then he replaced the coleoptile with a piece of agar and placed the coleoptile on top of the agar block. He proved that a signal must be transported from the coleoptile to the rest of the plant, as Darwin had originally deduced (Moore et al., 1995). In 1918, Arpad Paal accumulated the first evidence showing that growth signal is chemical in nature (Moore et al., 1995). In 1926, Went showed that the active growth substance from oat coleoptile tips can diffuse into a block of agar and maintain its stimulative effect of the growth of coleoptiles. He developed a bioassay called Avena test to identify and quantify the biological activity of this growth substances he called AUXIN (from Greek auxein, to increase, to grow) (Went, 1935). In the 30s, Kögl et al. (1933) isolated from human urine various substances including IAA (indole-3-acetic acid). After few mistakes, the IAA was finally identified as the molecule that stimulates coleoptile growth (Jacobs, 1979) and some years later was isolated from plants. Auxin has been described by Van der Lek (1941) and Haissig and Davis (1994). Practical application of auxin for rooting became possible when it was descovered that it also acts when added on the cut surface of cuttings (Hitchcock and Zimmerman, 1936). After the discovery of IAA, IBA (indolic3-butyric acid) and NAA (1-naphthalene acetic acid) were synthesized chemically, their capability to induce roots was discovered by Zimmerman and Wilcoxon, 1935, and talc powder was introduced as a carrier for auxin (Grace, 1937).

IBA is used for rooting in commercial operations, followed by IAA and NAA and chemical analogues synthesized and examined for auxin-like activity. Auxin enters cuttings mostly via the cut surface (Kenney et al., 1969), even in microcuttings that are known to have a poorly functioning epidermis (Guan and De Klerk, 2000) and is rapidly taken up in cells by $\mathrm{pH}$ trapping (Rubery and Sheldrake, 1973) and by influx carriers (Delbarre et al., 1996). Auxin metabolism studies on adventitious rooting have been done on cuttings exposed for a prolonged period to auxin, but in other studies cuttings have been exposed to auxin for short periods (Diaz-Sala et al., 1996; Liu and Reid, 1992) An optimal auxin concentration for one of the three phases may be supraoptimal or suboptimal for the next. It was observed that apple microcuttings cultured continuously on medium with auxin (IAA, IBA or NAA) show the best rooting performance (a large number of roots is formed over a broad range of auxin concentrations) when cultured with IAA (de Klerk et al., 1997). Although roots may be induced by auxin, wounding is usually required to achieve rooting and it was suggested that WRCs (wounding-related compounds) play a main role in the dedifferentiation phase (de Klerk et al., 1999).

\section{Auxin effect on adventitious rooting}

Auxin and ethylene are often described as activators, while cytokinins and gibberellins are seen as inhibitors of adventitious root formation, even when some positive effects have been observed. The widely used sources of growth hormones for cuttings rooting are the IBA, NAA, IAA and commercialization root promoters (root-growing powders). The successful formation of adventitious roots is an obligatory phase of vegetative propagation in many woody plants; this being related to the presence of auxin 
(Kim et al., 1998; McClelland et al., 1990). IAA was the first used to stimulate rooting of cuttings (Cooper, 1935) and soon after another auxin which also promoted rooting, IBA, was discovered and was considered even more effective (Zimmerman and Wilcoxon, 1935). Nowadays IBA is used commercially to root microcuttings and is more efficient than IAA (Epstein and Ludwig-Müller, 1993).

Auxin is one of the major endogenous hormones known to be intimately involved in the process of adventitious rooting (Wiesman et al., 1988) and the physiological stages of rooting are correlated with changes in endogenous auxin concentrations (Heloir et al., 1996). High endogenous auxin concentration is normally associated with a high rooting rate at the beginning of the rooting process (Blažková et al., 1997; Caboni et al., 1997). Auxins have been shown to be effective inducers of adventitious roots in many woody species (de Klerk et al., 1999; Diaz-Sala et al., 1996; Goldfarb et al., 1998; Selby et al., 1992) and are usually synthesized in the stem tip and tender leaves of aerial parts of plants and then transportted to the action site (Ljung et al., 2001). When applying exogenous auxin on cuttings, the endogenous auxin concentration reaches a peak after wounding (Gaspar et al., 1996; Gatineau et al., 1997) coinciding with the initiation of the rooting process. The importance of the auxin during the expression phase was demonstrated in Populus sp. (Bellamine et al., 1998). Rice mutants affected in the expression of PINFORMEDl (OsPIN1) gene, potentially involved in auxin polar transport, are affected in adventitious root emergence and tillering confirming that the auxin concentration and distribution in the different tissues is important (Xu et al., 2005).

The pattern of auxin action, despite its crucial role in adventitious root development, is still poorly understood. In Arabidopsis, the superroot (sur 1 and sur2) mutants accumulate IAA and develop numerous adventitious roots on the hypocotyl and cuttings of different organs in the case of surl (Boerjan et al., 1995; Delarue et al., 1998). Recently, differential roles for IAA and IBA have been found in the regulation of adventitious root formation from stem segments of Arabidopsis (Ludwig-Muller et al., 2005).

Several gain-of-function iaa mutations affect production of lateral or adventitious roots (Fukaki et al., 2002; Rogg et al., 2001; Tatematsu et al., 2004). TIBA, an auxin polar transport inhibitor, applied to the top of the hypocotyls lowered the rate of root formation (Fabijan et al., 1981). It was suggested that endogenous IAA and exogenous IBA might interact to promote adventitious rooting in Arabidopsis stem segments. The performance of IBA versus IAA can be explained by several possibilities: higher stability, differences in metabolism, differences in transport and IBA as a slow release source of IAA. The conversion of IBA to IAA occurs in many plant species (Ludwig-Muller et al., 2005). However, in microcuttings of Malus sp., IBA induced more roots than IAA although it was converted to IAA only at very low levels, suggesting that either IBA itself was active or that it modulated the activity of IAA (Van Der Kriken et al., 1992). Although many researchers thought growth hormone treatment would promote rooting of cuttings, improve rooting number and lower the rate of partial rooting, the rooting ratio decreased while the hormone concentration increased. High hormone concentrations have side effects on the root development (Edson et al., 1991; Mason, 1989). Auxin can increase the rate of ethylene biosynthesis (Riov and Yang, 1989) and stimulate the production of ethylene correlating with the fact that the ACC synthase 4 gene has been found to be an early auxin-induced gene (Abel et al., 1995). Auxin and ethylene relationship in root development has been shown by a number of isolated mutants that have resistance to both hormones. The potential auxin efflux component, AtPIN2, allelic to the ethylene-insensitive root 1 (EIR1) is an example (Muller et al., 1998). Analogously, axr2 is a dominant mutant that gives resistance to both ethylene and auxin (Wilson et al., 1990). IAA induced ethylene production may be a factor involved in the stimulation of adventitious rooting (Pan et al., 2002).

Studies have emphasized that polyamines play a role in adventitious rooting (Biondi et al., 1990; Hausman et al., 1994; Heloir et al., 1996) and a possible interrelationship between polyamines and auxin controlling rooting induction was suggested (Hausman et al., 1995).

\section{Genes asociated with the adventitious root formation}

Some mutants affected in hormone homeostasis or signaling are also affected in adventitious root formation. The ABA-deficient tomato mutants flacca and notabilis produce an excess of adventitious roots on the stems (Tal, 1966). Recently, it has been shown using notabilis mutant that adventitious root phenotype can be restored to wild type by expressing the LeNCEDI gene involved in ABA biosynthesis, suggesting that $\mathrm{ABA}$ can be a negative regulator of adventitious roots (Thompson et al., 2004). Mutants overproducing auxin in Arabidopsis, like sur 1 and sur2 (Boerjan et al., 1995; Delarue et al., 1998) or yucca (Zhao et al., 2001) produce adventitious roots on hypocotyls of light grown seedlings. SUR1 and SUR2 genes encode a C-S-lyase protein and the cytochrome P450 Cyp83B1, both involved in the indole glucosinolate pathway (Bak et al., 2001; Barlier et al., 2000; Mikkelsen et al., 2004). YUCCA1 gene encodes a flavin monooxygenase suitable for converting tryptamine in N-hydroxyl tryptamine in vitro (Zhao et al., 2001, 2002) and belongs to a family of YUCflavin mono-oxigenases from which 4 have a role in auxin biosynthesis (Cheng et al., 2006).

Temperature-sensitive Arabidopsis mutants ( $r r d 1, r r d 2$ and $r r d 4)$ affected in root redifferentiation were identified (Sugiyama, 2003) and it was suggested that RRDI and $R R D 2$ genes have a role in fundamental processes for active cell proliferation. $R R D 4$ is involved in the acquisition step of cell proliferation during callus initiation in hypocotyl 
310

explants. Other temperature-sensitive mutants defective in various stages of adventitious root formation were isolated (Konishi and Sugiyama, 2003). The root growth defective mutants $r g d 1$, rgd2 and $r g d 3$ became defective after the establishment of the root apical meristem. The ROOT INITIATION DEFECTIVE S (RIDS) gene was identified as the MOR1 / GEM gene encoding a microtubuleassociated protein (Konishi and Sugiyama, 2006). The rid 2-1 mutant is recessive temperature-sensitive mutant of Arabidopsis that was isolated by screening using adventitious root formation as an index phenotype. RID2 gene encodes an evolutionarily conserved methyltransferaselike protein, which was localized in the nucleus, contributing to the nucleolar activity for pre-rRNA processing (Ohbayashi et al., 2011).

The auxin insensitive rice mutant crll/arl1 (crown rootless 1 /adventitious rootless 1 ) defective in adventitious roots formation was identified (Inukai et al., 2005; Liu et al., 2005). CRL1/ARL1, an auxin-responsive gene, encodes a nuclear protein containing ASYMMETRIC LEAVES2 (AS2)/LATERAL ORGAN BOUNDARIES (LOB) domain (Inukai et al., 2005; Liu et al., 2005). CRL1/ARL1 can be considered as a positive regulator for crown root formation in rice. Phylogenetic reconstructions revealed that the allelic rice genes CRL1 and ARL1 (Liu et al., 2005), the maize gene RTCS (Taramino et al., 2007) and the Arabidopsis genes LBD16 and LBD29 (Shuai et al., 2002) are closely related. The genes have been involved in different aspects of root formation, CRL1/ARL1 and RTCS genes are localized in synthenic regions of the genomes and their loss of function results in similar phenotypes indicating orthologous functions during shoot-borne root formation (Hochholdinger and Zimmermann, 2008; Inukai et al., 2005). In Arabidopsis LBD16 and LBD29 genes are involved in lateral root formation (Okushima et al., 2007) and are activated by ARF7 and ARF19 which indicates that these $\mathrm{LOB}$ domain genes are early auxin responsive genes. Therefore, these closely related monocot and dicot LOB domain proteins all probably act early in auxin signaling in the root, yet in different developmental contexts: The rice gene is involved in shoot-borne and lateral root formation, the maize gene in shoot-borne root formation and the Arabidopsis genes in lateral root initiation (Hochholdinger and Zimmermann, 2008).

Researchers have identified several genes that regulate indeterminate root growth in Arabidopsis. SHORT-ROOT $(S H R)$ is a regulator of radial patterning and indeterminacy of Arabidopsis thaliana primary root. SHR mutant fails to initiate cell division following germination. $S H R$ is also required for the initiation and patterning of lateral root primordia, to maintain the indeterminate growth of lateral and anchor roots, regulating root-related developmental processes (Lucas et al., 2011).

Another related protein, SCARECROW $(S C R)$, has a similar role alongside $S H R$ (Benfey et al., 1993; DiLaurenzio et al., 1996). SHR and SCR genes encode closely related transcription factors belonging to the GRAS gene family (DiLaurenzio et al., 1996; Helariutta et al., 2000). $S H R$ has been demonstrated to directly regulate the expression of genes including SCR (Levesque et al., 2006) and a number of cell cycle components including the Dtype cyclin, CYCD6; 1 (Sozzani et al., 2010).

Genes related to the induction of adventitious rooting in forest species have been described (Goldfarb et al., 2003; Lindroth et al., 2001a, 2001b; Sanchez et al., 2007). Recently, two genes in pine were characterized, a $P$. radiata SCARECROW-LIKE1 gene (PrSCL1)(Sanchez et al., 2007) and P. radiata SHORT-ROOT (PrSHR)(Sole et al., 2008), both genes may play a role during the earliest stages of adventitious root formation. The expression of PrSHR gene during adventitious rooting is also affected by the presence of MDPUs (methylenedioxyphenyl urea) which could interact, directly or indirectly, with the auxinsignalling pathways in rooting-competent cuttings during adventitious rooting (Ricci et al., 2008). SCARECROW $(S C R)$ is a putative transcription factor, expressed in cortical and endodermal initials, and it is required for the asymmetric cell division that gives rise to cortex and endodermis and to other tissues in aerial organs of Arabidopsis thaliana (DiLaurenzio et al., 1996; Heidstra et al., 2004; Wysocka-Diller et al., 2000). Arabidospis SCR (AtSCR) is also involved in the establishment of quiescent center identity and in the maintenance of the stem cell status of the surrounding initial cells during embryonic pattern formation and postembryonal development (Sabatini et al., 2003), and its expression is associated with auxin distribution in the root apical meristem (DiLaurenzio et al., 1996; Sabatini et al., 1999).

$V v P R P 1$ and $V v P R P 2$, induced in stem cuttings of $V i$ tis vinifera $\mathrm{L}$. during rooting, encode proline-rich proteins. Induction of these genes is not enhanced by IAA treatment and the expression of the $V v P R P 1$ is wound-inducible. The results suggest that the genes have an important role in the initiation of new roots by altering the cell wall mechanical properties to enable root emergence increasing the plasticity of the cell wall (Thomas et al., 2003).

The gene expression pattern during adventitious root development of Pinus contorta was investigated. During the root initiation phase, genes involved in cell replication and cell wall weakening and a transcript encoding a PINHEAD/ZWILLE-like protein were upregulated, while genes related to auxin transport, photosynthesis and cell wall synthesis were downregulated. During the root elongation phase downregulation of transcripts encoding proteins involved in cell replication and stress occurred (Brinker et al., 2004). Transgenic lines expressing an active form of the Populus type-B cytokinin response regulator PtRR13 ( $\triangle \mathrm{DDK}$ PtRR13) have a delayed rooting phenotype and cause misregulation of CONTINUOUS VASCULAR RING1, a negative regulator of vascularization. Inappropriate cytokinin action via $\triangle \mathrm{DDKPtRR} 13$ expression appeared to disrupt adventitious root develop- 
ment $24 \mathrm{~h}$ after shoot excision, when root founder cells are hypothesized to be sensitive to the negative effects of cytokinin (Ramirez-Carvajal et al., 2009).

An Arabidopsis transgenic line overexpressing ARF17 developed fewer adventitious roots than wild-type plants, confirming the potential role of $A R F$ genes in the regulation of adventitious root development by auxin (Sorin $e t$ al., 2005). It was shown that $A R F 17$, a target of miR160, is a negative regulator, and $A R F 6$ and $A R F 8$, targets of $m i R 167$, are positive regulators of adventitious rooting. These results provide evidence of microRNA control of phenotypic variability and are an important step in understanding the molecular mechanisms regulating adventitious rooting (Gutierrez et al., 2009). The proteomic analysis of ago 1-3, sur 1-3, sur2-1 and the sur2-1 ago 1-3 double mutant led to the identification of 11 proteins, including three auxin-inducible GH3-like proteins, whose expression was altered by mutations, particularly in adventitious rooting formation. The results strongly suggest that those proteins will be valuable markers for quantitative genetic analysis of adventitious root development (Sorin et al., 2006).

MsAPK1, member of the plant kinases family containing the Ankyrin-Protein Kinases (APKs), is induced by osmotic stress in roots of Medicago sativa and is related to two APK genes in Arabidopsis thaliana, AtAPKI and AtAPK2. Promoter-GUS fusions assays revealed that Arabidopsis $A P K$ genes show distinct expression patterns in roots and hypocotyls. The DN mutant lines showed increased capacity to develop adventitious roots when compared with control or MsAPKI-expressing plants (Delphine et al., 2008).

In a study made on tomato mutants, the epi (epinastic) mutation increased adventitious root formation and the $\mathrm{Nr}$ (Never ripe) mutation reduced the number of adventitious roots (Negi et al., 2010). This indicates a negative role for ethylene in lateral root formation of tomatoes and a positive role in adventitious root formation with modulation of auxin transport as a central point of ethylene-auxin crosstalk (Negi et al., 2010). The treatment of tomatoes with AVG (aminoethoxyvinyglycine) and NPA (1-NNaphthylphthalamic acid) resulted in a reduction of adventitious roots in waterlogged plants. Ethylene, perceived by the $N r$ receptor, stimulated auxin transport. Auxin accumulation in the base of the plant induces growth of adventitious roots, forming a new root system capable of replacing the one damaged by submergence (Vidoz et al., 2010).

Auxin efflux carrier, PINI, is a highly conserved gene family, which may play a key role in polar auxin transport (Friml and Palme, 2002).The finding that OsPIN1 is involved in auxin-dependent adventitious root emergence and tillering provides a new insight into the function of the PINI family in rice (Xu et al., 2005). The rice gene OsCAND1, the homolog of Arabidopsis CAND1, is involved in auxin signaling to maintain the G2/M cell cycle transition in crown root meristem and the emergence of crown root, providing new information about the molecular regulation of the emergence of crown root (Wang et al., 2011).

\section{ARF and AUX/IAA involved in adventitious rooting}

Great progress has been made in recent years in understanding the auxin response genes and auxin signaling (Parry and Estelle, 2006; Quint et al., 2009). The response to auxin includes a rapid initial cell growth response that may involve auxin-induced changes in $\mathrm{pH}$, calcium and gene expression. Auxin response is regulated by $A U X /$ $I A A$ proteins and the ARF (Auxin Response Factor) proteins (Overvoorde et al., 2005). The $A U X / I A A$ genes are induced in response to auxin, encoding small nuclear proteins that share four domains (I, II, III and IV) and function as transcription factors that regulate downstream auxin responses (Guilfoyle and Hagen, 2007; Reed, 2001). AUX/IAA genes were identified in screens for mRNA transcripts induced rapidly by auxin. AUX/IAA proteins likely function as homodimers and/or heterodimers and have been found to interact in homotypic and heterotypic associations in yeast two-hybrid experiments, and these interactions were dependent on the presence of domains III and IV (Kim et al., 1997; Rouse et al., 1998). Arabidopsis has $29 A U X / I A A$ proteins which have four conserved domains called I-IV. Domain I is a transcriptional repression domain and can repress auxin gene induction responses (Kim et al., 1997; Tiwari et al., 2003). Domanin II is recognized by SCF ${ }^{\mathrm{TIR} 1}$ and probably other closely related E3 ubiquitin ligases (Kepinski and Leyser, 2005). Domains III and IV constitute a dimerization domain and can interact with similar motifs in ARF proteins (Ulmasov et al., 1999). Gain-of-function mutations in motif II of several IAA genes stabilize the corresponding protein and affect developmental responses to auxin. In several cases these mutations decrease auxin-induced gene expression (Tatematsu et al., 2004). AUX/IAA proteins have short half-lives, suggesting a primary role for protein degradation in the regulation of their activity. Guilfoyle $e t$ al. (1998) assumed that domain II was responsible for the rapid turnover of these proteins, because mutations in this domain (like axr3 mutants) led to a semidominant gainof-function phenotype (Guilfoyle et al., 1998). Worley et al. (2000) suggested that rapid degradation of $A U X / I A A$ proteins is essential for a normal auxin response. It was also found that overexpression of the IAA17 protein in Arabidopsis resulted in plants with an axr3-like phenotype (Worley et al., 2000). AUX/IAA proteins do not appear to bind DNA themselves but can affect the transcription of ARF-regulated genes by dimerising with ARFs (Guilfoyle and Hagen, 2007; Tiwari et al., 2003).

Auxin response factors $(A R F)$ are transcription factors that regulate the expression of auxin response genes (Guilfoyle and Hagen, 2007; Tiwari et al., 2003). Arabi- 
312

dopsis has 22 ARF proteins encoded by $22 A R F$ genes, each containing a conserved DNA binding domain near their $\mathrm{N}$ terminus and a dimerization domain near their $\mathrm{C}$ terminus that can interact with a corresponding domain in $A U X / I A A$ proteins (Ulmasov et al., 1999). The role of $A R F s$ in plant development and growth has been revealed by studies on arf mutants. Mutations were identified: arf7/ nonphototropic hypocotyl 4 (nph4), which present defects in hypocotyls tropisms and resistance to auxin and ethylene (Harper et al., 2000; Waller et al., 2002) and arf19, which show insensitivity to auxin and ethylene (Li et al., 2006). arf double mutants (Remington et al., 2004) have stronger phenotypes than the single mutants, suggesting that related ARFs might have redundant roles in Arabidopsis. Single mutants of arf7 and arf 19 have reduced lateral and adventitious root numbers, but arf 7 arf 19 double mutants have extremely reduced numbers of adventitious and lateral roots (Okushima et al., 2007; Wilmoth et al., 2005). While no phenotypic defects were reported for single mutants arf 10 or arf1 6, arf 10 arf 16 double mutants have root cap defects and abnormal root gravitropism (Wang et al., 2005).

Genetic studies have implicated different $A R F s$ in diverse growth processes. Highly specific and/or dynamic patterns of gene expression have been observed for ARF7 in seedlings, roots and embryos development (Hardtke et al., 2004; Okushima et al., 2005; Wilmoth et al., 2005), ARF10 in the root caps development, vascular tissue of roots and leaves (Wang et al., 2005), and ARF19 in seedlings and roots development ( $\mathrm{Li}$ et al., 2006; Okushima et al., 2005; Wilmoth et al., 2005). Mutations in ARF19 in combination with mutations in NPH4/ARF7, encoding the most closely related adventitious root, cause phenotypes like a drastic decrease in lateral and adventitious roots.

\section{Conclusions}

The process of adventitious root formation is very complex and plays a key role in the vegetative propagation of difficult-to-root genotypes. Although the importance of auxin in root development is well known, this plant hormone is not always efficient and the molecular mechanisms involved in the formation of adventitious roots are still partly unknown, despite the efforts done by researchers all over the world. For improving rooting conditions of economically important genotypes, scientists need to elucidate these molecular mechanisms through which auxin regulate adventitious rooting. Characterizing adventitious rooting mutants and identifying the genes responsible for the mutations leads to a better understanding of the regulation of the adventitious rooting mechanisms. New information on $A R F$ s and $A U X / I A A$ roles in plant growth and development has been revealed in the past years by forward and reverse genetic studies. Candidate genes regulated by $A R F$, which may function in these mechanisms, have been identified experimentally or predicted from data mining. Unfortunately, the adventitious root response genes are still not entirely identified, therefore this process represents an area open for research.

\section{References}

Abel S, Nguyen MD, Chow W, Theologis A (1995). ACS4, a primary indoleacetic acid-responsive gene encoding 1-aminocyclopropane-1-carboxylate synthase in Arabidopsis thaliana. Structural characterization, expression in Escherichia coli, and expression characteristics in response to auxin [corrected]. J Biol Chem 270(32):19093-19099.

Bak S, Tax FE, Feldmann KA, Galbraith DW, Feyereisen R (2001). CYP83B1, a cytochrome P450 at the metabolic branch point in auxin and indole glucosinolate biosynthesis in Arabidopsis thaliana. Plant Cell 12:101-111.

Barlier I, Kowalczyk M, Marchant A, Ljung K, Bhalerao R, Bennett M, Sandberg G, Bellini C (2000). The SUR2 gene of Arabidopsis thaliana encodes the cytochrome P450 CYP83B1, a modulator of auxin homeostasis. Proc Natl Acad Sci USA 97(26):14819-14824.

Bellamine J, Penel C, Greppin H, Gaspar T (1998). Confirmation of the role of auxin and calcium in the late phases of adventitious root formation. Plant Grow Regul 26(3):191-194.

Benfey PN, Linstead PJ, Roberts K, Schiefelbein JW, Hauser MT, Aeschbacher RA (1993). Root Development in Arabidopsis-4 Mutants with Dramatically Altered Root Morphogenesis. Develop 119(1):57-70.

Biondi S, Diaz T, Iglesias I, Gamberini G, Bagni N (1990). Polyamines and ethylene in relation to adventitious root formation in Prunus avium shoot cultures. Physiol Plant 78(3):474-483.

Blažková A, Sotta B, Tranvan H, Maldiney R, Bonnet M, Einhorn J, Kerhoas L, Miginiac E (1997). Auxin metabolism and rooting in young and mature clones of Sequoia sempervirens. Physiol Plant 99(1):73-80.

Boerjan W, Cervera MT, Delarue M, Beeckman T, Dewitte W, Bellini C, Caboche M, Onckelen HV, Montagu MV, Inze D (1995). Superroot, a Recessive Mutation in Arabidopsis, Confers Auxin Overproduction. Plant Cell Online 7(9):1405-1419.

Brinker M, van Zyl L, Liu WB, Craig D, Sederoff RR, Clapham DH, von Arnold S (2004). Microarray analyses of gene expression during adventitious root development in Pinus contorta. Plant Physiol 135(3):1526-1539.

Caboni E, Tonelli MG, Lauri P, Iacovacci P, Kevers C, Damiano C, Gaspar T (1997). Biochemical aspects of almond microcuttings related to in vitro rooting ability. Biol Plant 39:91-97.

Cheng Y, Dai X, Zhao Y (2006). Auxin biosynthesis by the YUCCA flavin monooxygenases controls the formation of floral organs and vascular tissues in Arabidopsis. Genes Dev 20(13):1790-1799.

Cooper WC (1935). Hormones in relation to root formation 
on stem cuttings. Plant Physiol 10:789-794.

Darwin C (1880). The Power of Movement in Plants. London: John Murray.

Davies PJ (2004). Plant hormones: Biosynthesis, Signal Transduction, Action! Dordrecht, Kluwer Academic Publishers, The Netherlands.

De Klerk GJ, van der Krieken W, de Jong J (1999). Review the formation of adventitious roots: New concepts, new possibilities. In Vitro Cell Develop Biol Plant 35(3):189199.

De Klerk GJ, Ter Bruge J, Marinova S (1997). Effectiveness of indoleacetic acid, indolebutyric acid and naphthalene acetic acid during adventitious root formation in vitro in Malus 'Jork 9'. Plant Cell Tiss Organ Cult 49:39-44.

Delarue M, Prinsen E, Onckelen HV, Caboche M, Bellini C (1998). Sur2 mutations of Arabidopsis thaliana define a new locus involved in the control of auxin homeostasis. Plant J 14(5):603-611.

Delbarre A, Müller P, Imhoff V, Guern J (1996). Comparison of mechanisms controlling uptake and accumulation of 2,4-dichlorophenoxy acetic acid, naphthalene-1-acetic acid, and indole-3-acetic acid in suspension-cultured tobacco cells. Planta 198:532-541.

Delphine C, Frugier F, Raices M, Merchan F, Giammaria V, Gargantini P, Gonzalez-Rizzo S, Crespi M, Ulloa R (2008). A mutant ankyrin protein kinase from Medicago sativa affects Arabidopsis adventitious roots. Funct Plant Biol 35(1):92-101.

Diaz-Sala C, Hutchison KW, Goldfarb B, Greenwood MS (1996). Maturation-related loss in rooting competence by loblolly pine stem cuttings: The role of auxin transport, metabolism and tissue sensitivity. Physiol Plant 97(3):481490.

DiLaurenzio L, WysockaDiller J, Malamy JE, Pysh L, Helariutta Y, Freshour G, Hahn MG, Feldmann KA, Benfey PN (1996). The SCARECROW gene regulates an asymmetric cell division that is essential for generating the radial organization of the Arabidopsis root. Cell 86(3):423-433.

Edson JL, Wenny D, Fins L (1991). Propagation of Western Larch by Stem Cuttings. West J Appl Forest 6:47-49.

Epstein E, Ludwig-Müller J (1993). Indole-3-butyric acid in plants: occurrence, synthesis, metabolism and transport. Physiol Plant 88:382-389.

Fabijan D, Taylor JS, Reid DM (1981). Adventitious rooting in hypocotyls of sunflower (Helianthus annuus) seedlings. Physiol Plant 53(4):589-597.

Friml J, Palme K (2002). Polar auxin transport-old questions and new concepts? Plant Mol Biol 49(3-4):273-284.

Fukaki H, Tameda S, Masuda H, Tasaka M (2002). Lateral root formation is blocked by a gain-of-function mutation in the SOLITARY-ROOT/IAA14 gene of Arabidopsis. Plant J 29(2):153-168.

Gaspar T, Kevers C, Penel C, Greppin H, Reid D, Thorpe T
313

(1996). Plant hormones and plant growth regulators in plant tissue culture. In Vitro Cell Develop Biol Plant 32(4):272289.

Gatineau F, Fouche JG, Kevers C, Hausman JF, Gaspar T (1997). Quantitative variations of indolyl compounds including IAA, IAA aspartate and serotonin in walnut microcuttings during root induction. Biol Plant 39:131-137.

Geiss G, Gutierrez L, Bellini C (2009). Adventitious Root Formation: New Insights and Perspectives, WileyBlackwell.

Goldfarb B, Hackett WP, Furnier GR, Mohn CA, Plietzsch A (1998). Adventitious root initiation in hypocotyl and epicotyl cuttings of eastern white pine (Pinus strobus) seedlings. Physiol Plant 102(4):513-522.

Goldfarb B, Lanz-Garcia C, Lian ZG, Whetten R (2003). AUX/ $I A A$ gene family is conserved in the gymnosperm, loblolly pine (Pinus taeda). Tree Physiol 23(17):1181-1192.

Grace NH (1937). Physiologic curve of response to phytohormones by seeds, growing plants, cuttings and lower plant forms. Can J Res C 15:538-546.

Guan H, De Klerk GJ (2000). Stem segments of apple microcuttings take up auxin predominantly via the cut surface and not via the epidermal surface. Sci Horti 86: 23 32

Guilfoyle TJ, Hagen G (2007). Auxin response factors. Current Opin Plant Biol 10(5):453-460.

Guilfoyle TJ, Ulmasov T, Hagen G (1998). The ARF family of transcription factors and their role in plant hormoneresponsive transcription. Cell Mol Life Sci 54(7):619-627.

Gutierrez L, Bussell JD, Pacurar DI, Schwambach J, Pacurar M, Bellini C (2009). Phenotypic plasticity of adventitious rooting in Arabidopsis is controlled by complex regulation of auxin response factor transcripts and MicroRNA Abundance. Plant Cell 21(10):3119-3132.

Haissig BE, Davis TD (1994). An historical evaluation of adventitious rooting research to 1993, p. 275-331. In: Davis TD, Haissig BE (Eds.). Biology of adventitious root formation. New York, London: Plenum Publishing Corporation.

Han H, Zhang S, Sun X (2009). A review on the molecular mechanism of plants rooting modulated by auxin. Afr J Biotech 8(3):348-353

Hardtke CS, Ckurshumova W, Vidaurre DP, Singh SA, Stamatiou G, Tiwari SB, Hagen G, Guilfoyle TJ, Berleth T (2004). Overlapping and non-redundant functions of the Arabidopsis Auxin Response Factors MONOPTEROS and NONPHOTOTROPIC HYPOCOTYL 4. Develop 131(5):1089-1100.

Harper RM, Stowe-Evans EL, Luesse DR, Muto H, Tatematsu K, Watahiki MK, Yamamoto K, Liscum E (2000). The NPH4 locus encodes the auxin response factor ARF7, a conditional regulator of differential growth in aerial Arabidopsis tissue. Plant Cell 12(5):757-770. 
314

Hartmann HT, KesterDE, Davies FT (1990). Plant Propagation: Principles and Practices. Prentice-Hall, Englewood Cliffs, NJ $5^{\text {th }}$ ed., p. 647.

Hausman JF, Gevers C, Gaspar T (1994). Involvement of putrescine in the inductive rooting phase of poplar shoots raised in vitro. Physiol Plant 92(2):201-206.

Hausman JF, Kevers C, Gaspar T (1995). Auxin-polyamine interaction in the control of the rooting inductive phase of poplar shoots in vitro. Plant Sci 110(1): 63-71.

Heidstra R, Welch D, Scheres B (2004). Mosaic analyses using marked activation and deletion clones dissect Arabidopsis $S C A R E C R O W$ action in asymmetric cell division. Genes Dev 18:1964-1969.

Helariutta Y, Fukaki H, Wysocka-Diller J, Nakajima K, Jung J, Sena G, Hauser MT, Benfey PN (2000). The SHORTROOT gene controls radial patterning of the Arabidopsis root through radial signaling. Cell 101(5):555-567.

Heloir MC, Kevers C, Hausman JF, Gaspar T (1996). Changes in the concentrations of auxins and polyamines during rooting of in-vitro-propagated walnut shoots. Tree Physiol $16(5): 515-519$.

Hitchcock AE, Zimmerman PW (1936). Effect of the use of growth substances on the rooting response of cuttings. Contrib. Boyce Thompson Inst 8:63-79.

Hochholdinger F, Park WJ, Sauer M, Woll K (2004). From weeds to crops: genetic analysis of root development in cereals. Trends Plant Sci 9(1):42-48.

Hochholdinger F, Zimmermann R (2008). Conserved and diverse mechanisms in root development. Current Opin Plant Biol 11(1):70-74.

Inukai Y, Sakamoto T, Ueguchi-Tanaka M, Shibata Y, Gomi K, Umemura I, Hasegawa Y, Ashikari M, Kitano H, Matsuoka M (2005). Crown rootless1, which is essential for crown root formation in rice, is a target of an auxin response factor in auxin signaling. Plant Cell 17(5):1387-1396.

Jacobs WP (1979). Plant hormones and plant development. Cambridge, UK: Cambridge University Press.

Jaillais Y, Chory J (2010). Unraveling the paradoxes of plant hormone signaling integration. Nat Struct Mol Biol $17(6): 642-645$.

Kende H, Zeevaart J (1997). The Five "Classical" Plant Hormones. Plant Cell 9(7):1197-1210.

Kenney G, Sudi J, Blackman GE (1969). The uptake of growth substances XIII. Differential uptake of indole-3yl-acetic acid through the epidermal and cut surfaces of etiolated stem segments. J Exp Bot 20:820-840.

Kepinski S, Leyser O (2005). Plant development: auxin in loops. Curr Biol 15(6):208-210.

Kevers C, Hausman JE, Faivre-Rampant O, Evers D, Gaspar T (1997). Hormonal control of adventitious rooting: progress and questions. J Appl Bot Angew Bot 71:71-79.

Kim J, Harter K, Theologis A (1997). Protein-Protein Interactions among the $A U X / I A A$ Proteins. Proceed Nati

\section{Acad Sci USA 94(22):11786-11791.}

Kim MS, Klopfenstein NB, Cregg BM (1998). In vitro and ex vitro rooting of micropropagated shoots using three green ash (Fraxinus pennsylvanica) clones. New For 16:43-57.

Kögl F, Haagen-Smit AJ, Erxleben H (1933). Z Physiol Chem, 241.

Konishi M, Sugiyama M (2003). Genetic analysis of adventitious root formation with a novel series of temperature-sensitive mutants of Arabidopsis thaliana. Develop 130(23):56375647.

Konishi M, Sugiyama M (2006). A Novel Plant-Specific Family Gene, Root Primordium Defective 1, is Required for the Maintenance of Active Cell Proliferation. Plant Physiol 140(2):591-602.

Levesque MP, Vernoux T, Busch W, Cui HC, Wang JY, Blilou I, Hassan H, Nakajima K, Matsumoto N, Lohmann JU, Scheres B, Benfey PN (2006). Whole-genome analysis of the SHORT-ROOT developmental pathway in Arabidopsis. Plos Biol 4(5):739-752.

Li J, Dai X, Zhao Y (2006). A role for auxin response factor 19 in auxin and ethylene signaling in Arabidopsis. Plant Physiol 140(3):899-908.

Li SW, Xue L, Xu S, Feng H, An L (2009). Mediators, Genes and Signaling in Adventitious Rooting. The Bot Rev 75(2):230247.

Lindroth AM, Kvarnheden A, von Arnold S (2001a). Isolation of a PSTAIRE CDC2 cDNA from Pinus contorta and its expression during adventitious root development. Plant Physiol Biochem 39(2):107-114.

Lindroth AM, Saarikoski P, Flygh G, Clapham D, Gronroos R, Thelander M, Ronne H, von Arnold S (2001b). Two S-adenosylmethionine synthetase-encoding genes differentially expressed during adventitious root development in Pinus contorta. Plant Mol Biol 46(3):335-346.

Liu HJ, Wang SF, Yu XB, Yu J, He XW, Zhang SL, Shou HX, Wu P (2005). ARL1, a LOB-domain protein required for adventitious root formation in rice. Plant J 43(1):47-56.

Liu HJ, Reid DM (1992). Auxin and ethylene-stimulated adventitious rooting in relation to tissue sensitivity to auxin and ethylene production in sunflower hypocotyls. J Exp Bot 43:1191-1198.

Ljung K, Bhalerao RP, Sandberg G (2001). Sites and homeostatic control of auxin biosynthesis in Arabidopsis during vegetative growth. Plant J 28(4):465-474.

Lucas M, Swarup R, Paponov IA, Swarup K, Casimiro I, Lake D, Peret B, Zappala S, Mairhofer S, Whitworth M, Wang JH, Ljung K, Marchant A, Sandberg G, Holdsworth MJ, Palme K, Pridmore T, Mooney S, Bennett MJ (2011). SHORTROOT Regulates Primary, Lateral, and Adventitious Root Development in Arabidopsis. Plant Physiol 155(1):384398.

Ludwig-Muller J, Vertocnik A, Town CD (2005). Analysis of indole-3-butyric acid-induced adventitious root formation on Arabidopsis stem segments. J Exp Bot 56(418):2095- 
2105.

Mason WL (1989). Vegetative propagation of hybrid larch (Larix $\times$ eurolepis Henry) using winter cuttings. For Suppl 62:189-199.

McClelland MT, Smith MAL, Carothers ZB (1990). The effects of in vitro and ex vitro root initiation on subsequent microcutting root quality in three woody plants. Plant Cell Tissue Org Cult (Historical Archive) 23:115-123.

Mellerowicz EJ, Baucher M, Sundberg B, Boerjan W (2001). Unravelling cell wall formation in the woody dicot stem. Plant Mol Biol 47(1-2):239-274.

Mikkelsen MD, Naur P, Halkier BA (2004). Arabidopsis mutants in the C-S lyase of glucosinolate biosynthesis establish a critical role for indole-3-acetaldoxime in auxin homeostasis. Plant J 37(5):770-777.

Moore R, Clark DW, Stern KR, Vodopich D (1995). Botany. Wm. C. Brown Communications Inc., Dubuque, USA.

Muller A, Guan C, Galweiler L, Tanzler P, Huijser P, Marchant A, Parry G, Bennett M, Wisman E, Palme K (1998). AtPIN2 defines a locus of Arabidopsis for root gravitropism control. Embo J 17(23):6903-6911.

Negi S, Sukumar P, Liu X, Cohen JD, Muday GK (2010). Genetic dissection of the role of ethylene in regulating auxin-dependent lateral and adventitious root formation in tomato. Plant J 61(1):3-15.

Nemhauser JL, Hong F, Chory J (2006). Different plant hormones regulate similar processes through largely nonoverlapping transcriptional responses. Cell 126(3):467475.

Ohbayashi I, Konishi M, Ebine K, Sugiyama M (2011). Genetic identification of Arabidopsis RID2 as an essential factor involved in pre-rRNA processing. The Plant $\mathrm{J}$ doi: 10.1111/j.1365-313X.2011.04574.x.

Okushima Y, Fukaki H, Onoda M, Theologis A, Tasaka M (2007). ARF7 and ARF19 regulate lateral root formation via direct activation of LBD/ASL genes in Arabidopsis. Plant Cell 19(1):118-130.

Okushima Y, Overvoorde PJ, Arima K, Alonso JM, Chan A, Chang C, Ecker JR, Hughes B, Lui A, Nguyen D, Onodera C, Quach H, Smith A, Yu G, Theologis A (2005). Functional genomic analysis of the auxin response factor gene family members in Arabidopsis thaliana: unique and overlapping functions of ARF7 and ARF19. Plant Cell 17(2):444-463.

Osmont KS, Sibout R, Hardtke CS (2007). Hidden branches: Developments in root system architecture. Ann Rev Plant Biol 58:93-113.

Overvoorde PJ, Okushima Y, Alonso JM, Chan A, Chang C, Ecker JR, Hughes B, Liu A, Onodera C, Quach H, Smith A, Yu G, Theologis A (2005). Functional genomic analysis of the auxin/indole-3-acetic acid gene family members in Arabidopsis thaliana. Plant Cell 17(12):3282-3300.

Pan R, Wang J, Tian X (2002). Influence of ethylene on adventitious root formation in mung bean hypocotyl cuttings. Plant Grow Regul 36(2):135-139.

Parry G, Estelle M (2006). Auxin receptors: a new role for F-box proteins. Curr Opin Cell Biol 18(2):152-156.

Quint M, Barkawi LS, Fan KT, Cohen JD, Gray WM (2009). Arabidopsis IAR4 modulates auxin response by regulating auxin homeostasis. Plant Physiol 150(2):748-758.

Ramirez-Carvajal GA, Morse AM, Dervinis C, Davis JM (2009). The Cytokinin Type-B Response Regulator PtRR13 Is a Negative Regulator of Adventitious Root Development in Populus. Plant Physiol 150(2):759-771.

Reed JW (2001). Roles and activities of $A U X / I A A$ proteins in Arabidopsis. Trends in Plant Sci 6(9):420-425.

Remington DL, Vision TJ, Guilfoyle TJ, Reed JW (2004). Contrasting modes of diversification in the $A U X / I A A$ and ARF gene families. Plant Physiol 135(3):1738-1752.

Ricci A, Rolli E, Dramis L, Diaz-Sala C (2008). N,N ‘-bis(2,3-methylenedioxyphenyl)urea and N,N '-bis-(3,4methylenedioxyphenyl)urea enhance adventitious rooting in Pinus radiata and affect expression of genes induced during adventitious rooting in the presence of exogenous auxin. Plant Sci 175(3):356-363.

Riov J, Yang S (1989). Ethylene and auxin-ethylene interaction in adventitious root formation in mung bean (Vigna radiata) cuttings. J Plant Grow Regul 8(2):131-141.

Rogg LE, Lasswell J, Bartel B (2001). A gain-of-function mutation in IAA28 suppresses lateral root development. Plant Cell 13(3):465-480.

Rouse D, Mackay P, Stirnberg P, Estelle M, Leyser O (1998). Changes in auxin response from mutations in an $A U X / I A A$ gene. Sci 279(5355):1371-1373.

Rubery PH, Sheldrake AR (1973). Effect of $\mathrm{pH}$ and surface charge on cell uptake of auxin. Nat New Biol 244(139):285288.

Sabatini S, Beis D, Wolkenfelt H, Murfett J, Guilfoyle T, Malamy J, Benfey P, Leyser O, Bechtold N, Weisbeek P, Scheres B (1999). An auxin-dependent distal organizer of pattern and polarity in the Arabidopsis root. Cell 99(5):463-472.

Sabatini S, Heidstra R, Wildwater M, Scheres B (2003). SCARECROW is involved in positioning the stem cell niche in the Arabidopsis root meristem. Genes Dev 17(3):354-358.

Sanchez C, Vielba JM, Ferro E, Covelo G, Sole A, Abarca D, De Mier BS, Diaz-Sala C (2007). Two SCARECROW-LIKE genes are induced in response to exogenous auxin in rootingcompetent cuttings of distantly related forest species. Tree Physiol 27(10):1459-1470.

Santner A, Estelle M (2009). Recent advances and emerging trends in plant hormone signalling. Nature 459(7250):10711078.

Shuai B, Reynaga-Pena CG, Springer PS (2002). The lateral organ boundaries gene defines a novel, plant-specific gene family. Plant Physiol 129(2):747-761.

Sole A, Sanchez C, Vielba JM, Valladares S, Abarca D, Diaz-Sala 
316

C (2008). Characterization and expression of a Pinus radiata putative ortholog to the Arabidopsis SHORT-ROOT gene. Tree Physiol 28(11):1629-1639.

Sorin C, Bussell JD, Camus I, Ljung K, Kowalczyk M, Geiss G, McKhann H, Garcion C, Vaucheret H, Sandberg G, Bellini C (2005). Auxin and light control of adventitious rooting in Arabidopsis require ARGONAUTE1. Plant Cell $17(5): 1343-1359$.

Sorin C, NegroniL, Balliau T, Corti H, JacquemotMP, Davanture M, Sandberg G, Zivy M, Bellini C (2006). Proteomic analysis of different mutant genotypes of Arabidopsis led to the identification of 11 proteins correlating with adventitious root development. Plant Physiol 140(1):349-364.

Sozzani R, Cui H, Moreno-Risueno MA, Busch W, Van Norman JM, Vernoux T, Brady SM, Dewitte W, Murray JAH, Benfey PN (2010). Spatiotemporal regulation of cellcycle genes by shortroot links patterning and growth. Nature 466(7302):128-149.

Sugiyama M (2003). Isolation and initial characterization of temperature-sensitive mutants of Arabidopsis thaliana that are impaired in root redifferentiation. Plant Cell Physiol $44(6): 588-596$.

Tal M (1966). Abnormal stomatal behavior in wilty mutants of tomato. Plant Physiol 41:1387-1391.

Taramino G, Sauer M, Stauffer JL, Multani D, Niu XM, Sakai H, Hochholdinger F (2007). The maize (Zea mays L.) RTCS gene encodes a LOB domain protein that is a key regulator of embryonic seminal and post-embryonic shoot-borne root initiation. Plant J 50(4):649-659.

Tatematsu K, Kumagai S, Muto H, Sato A, Watahiki MK, Harper RM, Liscum E, Yamamoto KT (2004). MASSUGU2 encodes $A U X / I A A 19$, an auxin-regulated protein that functions together with the transcriptional activator NPH4/ ARF7 to regulate differential growth responses of hypocotyl and formation of lateral roots in Arabidopsis thaliana. Plant Cell 16(2):379-393.

Thomas P, Lee MM, Schiefelbein J (2003). Molecular identification of proline-rich protein genes induced during root formation in grape (Vitis vinifera L.) stem cuttings. Plant Cell Environ 26(9):1497-1504.

Thompson AJ, Thorne ET, Burbidge A, Jackson AC, Sharp RE, Taylor IB (2004). Complementation of notabilis, an abscisic acid-deficient mutant of tomato: importance of sequence context and utility of partial complementation. Plant Cell Environ 27(4):459-471.

Tiwari SB, Hagen G, Guilfoyle T (2003). The roles of auxin response factor domains in auxin-responsive transcription. Plant Cell 15(2):533-543.

Ulmasov T, Hagen G, Guilfoyle TJ (1999). Activation and repression of transcription by auxin-response factors. Proc Natl Acad Sci USA 96(10):5844-5849.

Van Der Kriken WM, Breteler H, Visser MHM (1992). Uptake and metabolism of indolebutyric acid during root formation on Malus microcuttings. Acta Bot Neerlandica 41:435-442.

Van der Lek HAA (1941). Over eenige toepasingen van 'groeistoffen' in de practijk van de plantenteelt. Vakbl Biol
22:29-35.

Vidoz ML, Loreti E, Mensuali A, Alpi A, Perata P (2010). Hormonal interplay during adventitious root formation in flooded tomato plants. Plant J 63(4):551-562.

Waller F, Furuya M, Nick P (2002). OsARF1, an auxin response factor from rice, is auxin-regulated and classifies as a primary auxin responsive gene. Plant $\mathrm{Mol}$ Biol 50(3):415-425.

Wang JW, Wang LJ, Mao YB, Cai WJ, Xue HW, Chen XY (2005). Control of root cap formation by MicroRNAtargeted auxin response factors in Arabidopsis. Plant Cell $17(8): 2204-2216$.

Wang XF, He FF, Ma XX, Mao CZ, Hodgman C, Lu CG, Wu P (2011). OsCAND1 Is Required for Crown Root Emergence in Rice. Mol Plant 4(2):289-299.

Went FW (1935). Auxin, the plant growth hormone. Bot Rev $1: 162-182$.

Went FW, Thimann KV (1937). Phytohormones. New York, The Macmillan Company.

Wiesman Z, Riov J, Epstein E (1988). Comparison of movement and metabolism of indole-3-acetic acid and indole-3-butyric acid in mung bean cuttings. Physiol Plant 74(3):556-560.

Wilmoth JC, Wang S, Tiwari SB, Joshi AD, Hagen G, Guilfoyle TJ, Alonso JM, Ecker JR, Reed JW (2005). NPH4/ARF7 and ARF19 promote leaf expansion and auxin-induced lateral root formation. Plant J 43(1):118-130.

Wilson AK, Pickett FB, Turner JC, Estelle M (1990). A dominant mutation in Arabidopsis confers resistance to auxin, ethylene and abscisic acid. Mol Gen Genetics 222(2):377-383.

Woodward AW, Bartel B (2005). Auxin: regulation, action, and interaction. Ann Bot 95(5):707-735.

Worley CK, Zenser N, Ramos J, Rouse D, Leyser O, Theologis A, Callis J (2000). Degradation of $A U X / I A A$ proteins is essential for normal auxin signalling. Plant J 21:553-562.

Wysocka-Diller JW, Helariutta Y, Fukaki H, Malamy JE, Benfey PN (2000). Molecular analysis of SCARECROW function reveals a radial patterning mechanism common to root and shoot. Develop 127(3):595-603.

Xu M, Zhu L, Shou H, Wu P (2005). A PIN1 family gene, OsPIN1, involved in auxin-dependent adventitious root emergence and tillering in rice. Plant Cell Physiol 46(10):1674-1681.

Zhao Y, Christensen SK, Fankhauser C, Cashman JR, Cohen JD, Weigel D, Chory J (2001). A Role for Flavin Monooxygenase-Like Enzymes in Auxin Biosynthesis. Sci 291(5502):306-309.

Zhao Y, Hull AK, Gupta NR, Goss KA, Alonso J, Ecker JR, Normanly J, Chory J, Celenza JL (2002). Trp-dependent auxin biosynthesis in Arabidopsis: involvement of cytochrome P450s CYP79B2 and CYP79B3. Genes Dev 16(23):3100-3112.

Zimmerman PW, Wilcoxon F (1935). Several chemical growth substances which cause initiation of roots and other responses in plants. Contrib Boyce Thompson Inst 7:209-229. 